\title{
Contentious colonies: The positional power of imperial peripheries
}

\author{
Sindre Gade Viksand* (D) \\ Department of Political Science, Lund University, Sweden \\ ${ }^{\star}$ Corresponding author. Email: sindre_gade.viksand@svet.lu.se
}

(Received 27 November 2019; revised 23 April 2020; accepted 4 May 2020; first published online 4 June 2020)

\begin{abstract}
While structural models of empire have recently re-emerged in the theoretical debates in the field of International Relations, a lack of attention has been paid to peripheral actors therein. This is particularly true for the analysis of the peripheries' relations with polities outside the imperial structure of which the peripheries are a part. In this article, I build a framework to better understand how these extra-imperial ties are translated into peripheral positional power. This framework is constructed on the basis of three core arguments. First, to theorise peripheral power, peripheries need to be positioned in networks outside the imperial structure. Second, the positional power of peripheries depends on the quality of the ties they have to external actors. Peripheries with dense and exclusive ties to external actors are more powerful than those with only sparse and non-exclusive ties. Third, from the different combinations of density and exclusivity arise not only variations in positional power, but also the likely strategies that are engaged in forming alliances with external actors. These logics are illustrated through the study of two cases of the diplomacy of decolonisation: the American Revolutionary War and the Angolan War of Independence.
\end{abstract}

Keywords: Empire; Colonial Diplomacy; Decolonisation; Social Network Theory; Power

\section{Introduction}

How do peripheral actors, entangled in hierarchical webs, enhance their relative power $v i s-\grave{a}$-vis the core? This has become an important question as the academic field of International Relations (IR) has recognised the importance of moving beyond the 'states under anarchy' framework, and as imperial and other hierarchical relationships have emerged as important analytical foci. ${ }^{1}$ This article focuses not on the hierarchical structure of empire in general, but on the peripheral units' position therein and the political strategies they wage when they challenge the control and authority of imperial metropoles. ${ }^{2}$ When they, in other words, engage in contentious politics. ${ }^{3}$

In these situations, peripheral power comes to the fore. But, in order to understand variations in this power, we need, I argue, to move outside the imperial structure. This is necessary for, in

\footnotetext{
${ }^{1}$ Daniel H. Nexon and Thomas Wright, 'What's at stake in the American empire debate', American Political Science Review, 101:2 (2007); Paul K. MacDonald, 'Those who forget historiography are doomed to republish it: Empire, imperialism and contemporary debates about American power', Review of International Studies, 35:1 (2009); Morten Skumsrud Andersen, 'Semi-cores in imperial relations: The cases of Scotland and Norway', Review of International Studies, 42:1 (2016).

${ }^{2}$ Although there are substantial differences between colonies and the general term peripheral actors, they are both here defined as the dominated actors in an imperial core-periphery structure.

${ }^{3}$ Doug McAdam, Sidney Tarrow, and Charles Tilly, Dynamics of Contention (Cambridge: Cambridge University Press, 2001). In particular, this article builds on Goddard and Nexon's larger project to bring the study of contentious politics into IR. See Stacie E. Goddard and Daniel H. Nexon, 'The dynamics of global power politics: A framework for analysis', Journal of Global Security Studies, 1:1 (2016).

(C) British International Studies Association 2020. This is an Open Access article, distributed under the terms of the Creative Commons Attribution licence (http://creativecommons.org/licenses/by/4.0/), which permits unrestricted re-use, distribution, and reproduction in any medium, provided the original work is properly cited.
} 
particular, two reasons. First, as Morten Skumsrud Andersen notes, structural models of empires have been committed to the opposition between core and periphery. ${ }^{4}$ Implicit in these models, therefore, is the theoretical argument that changes to intra-imperial ties explain the challenges to the imperial structure. Largely missing from these theoretical models is the extra-imperial structure in which both the core and the peripheries are situated. Both the core and the peripheries are entangled in international networks whose structures are likely to have an effect in the case of intra-imperial conflicts. Second, extra-imperial ties are particularly salient for peripheries, for whom successful challenges to imperial rule often depend on their ability to acquire external support. As Jeffrey Record argues, external assistance 'can alter the insurgent-government power ratio even to the point where the insurgency becomes the stronger side'. 5 Jason Lyall and Isiah Wilson back this claim up with quantitative evidence, demonstrating that external assistance divided into safe havens in neighbouring states and military and/or economic aid - have a significant impact on the probability of insurgent victory. ${ }^{6}$

So, what are the processes that lead external actors to assist imperial peripheries in their fights for independence? Often, answers to this question are metrocentric. ${ }^{7}$ The analytical focus is on imperial cores and the structural environments in which they are situated. This focus follows John Darwin's programmatic call to study the diplomacy of decolonisation through 'a careful reconstruction of the diplomacy through which the colonial powers sought ... to safeguard the substance of their imperial interests against the intrusion of other great power influence'. ${ }^{8}$ Paul MacDonald, for instance, finds that due to the legitimacy of colonial domination in the nineteenth century, European powers 'generally refrained from funneling assistance to guerillas fighting rival colonial powers'. ' In the twentieth century, in contrast, norms of self-determination and the superpowers' rejection of colonial empire's legitimacy stimulated an environment in which stronger powers - communist countries especially - were more 'willing to provide assistance to national liberation movements that sought to throw off the yoke of colonial domination'. ${ }^{10}$ Similarly, Ryan Griffiths argues that the post-1945 period is characterised as an 'environment in which the superpowers encouraged decolonization, and then competed for informal control over the emerging states.'11

While not disputing these general trends, I argue that by adding an analytical focus on the imperial peripheries themselves, we can better explain the processes that lead to external assistance. To this end, I propose a theoretical framework which (a) positions peripheries within extraimperial networks; (b) demonstrates the structural constraints, openings, and strategies that these networks give rise to; which, in turn, (c) explains why some peripheries are successful in acquiring external support and others are not. This framework is built on three core arguments. I argue, firstly, that in order to understand the international forces driving contentious colonies, we need to investigate the latter's positional power within international networks. Building on recent theoretical developments of network analysis in IR, ${ }^{12}$ and the network-relational approach to the

\footnotetext{
${ }^{4}$ Andersen, 'Semi-cores in imperial relations', p. 179.

${ }^{5}$ Jeffrey Record, 'External assistance: Enabler of insurgent success', Parameters, 36:3 (2006), p. 36.

${ }^{6}$ Jason Lyall and Isiah Wilson III, 'Rage against the machines: Explaining outcomes in counterinsurgency wars', International Organization, 63:1 (2009).

${ }^{7}$ A term I borrow from Michael W. Doyle, Empires (Ithaca: Cornell University Press, 1986), p. 335.

${ }^{8}$ John Darwin, 'Diplomacy and decolonization', The Journal of Imperial and Commonwealth History, $28: 3$ (2000), p. 5.

${ }^{9}$ Paul K. MacDonald, "Retribution must succeed rebellion": The colonial origins of counterinsurgency failure', International Organization, 67:2 (2013), p. 266.

${ }^{10}$ Ibid.

${ }^{11}$ Ryan D. Griffiths, 'Secession and the invisible hand of the international system', Review of International Studies, 40:3 (2014), p. 560.

${ }^{12}$ Emile Hafner-Burton, M. Kahler, and Alexander H. Montgomery, 'Network analysis for international relations', International Organization, 63:3 (2009); Emile M. Hafner-Burton and Alexander H. Montgomery, 'Power positions: International organizations, social networks, and conflict', Journal of Conflict Resolution, 50:1 (2006); R. C. Carpenter, 'Vetting the advocacy agenda: Network centrality and the paradox of weapons norms', International Organization, 65:1
} 
study of empires, ${ }^{13}$ I argue that peripheries' positions in international networks significantly affect their ability to acquire external support.

While some relational studies of empire have noted the importance of ties to actors outside the imperial structure, they are yet to be explored in detail. Both Alexander Motyl and Daniel Nexon, for instance, discuss - albeit briefly - the role of foreign assistance. ${ }^{14}$ But neither explore this to the same extent as they attend to other features of imperial rule. Jeppe Mulich, in contrast, puts the peripheries and their external ties front and centre. ${ }^{15}$ Yet, he does not delineate how variations in these ties matter: neither the quality (that is, weak or dense) of the ties themselves nor to whom they connect are brought into his analysis. These two factors, I would argue, are crucial to understand the positional power of imperial peripheries, and thus their capacity to acquire external assistance.

Therefore, I argue, secondly, that we can determine peripheries' positional power by paying attention to two relational qualities of the social ties they form: density and exclusivity. Adopting the conventional definition in network theory, social ties are here conceptualised as containing 'weak' and 'dense' qualities, where weak ties are 'exchanges that are rare, unimportant, unidirectional, and fleeting' and dense ties are 'exchanges that are large in magnitude, reciprocal in character, and frequent and sustained over time'. ${ }^{16}$ The denser the social ties are, the more likely it is that sustained collective action between two units will occur. Just as dense ties are important to maintain core-periphery relations in imperial structures, ${ }^{17}$ I argue here that they are also crucial in mobilising actors outside the imperial structure.

But a tightly knit bond between two actors is oftentimes not enough for collective mobilisation. And, conversely, weak ties are sometimes sufficient for this purpose. Thus, this article highlights another quality of social ties: their exclusivity. For this article's purposes, exclusive ties are operationalised as when the external actor from which the peripheral unit seeks support is only weakly tied to the core of the imperial structure within which the peripheral unit exists. In the first of the cases studied below, the 13 American colonies are conceptualised as having exclusive ties to France due to the latter's weak ties to Britain. These weak ties, I argue, severely impeded Britain's opportunities to wedge apart an emerging Franco-American alliance. This wedging is precisely what happened in the second case study, in which different factions of the Angolan insurgents sought to form closer relationships with the United States, only for their efforts to be hampered by Portugal, who could use its ties to the West in NATO to force the US to disband any union with the different factions of the Angolan independence struggle.

Thirdly, I argue that the various combinations of density and exclusivity initiate different strategies in cementing external support. While actors with weak ties to an external actor need to bind themselves to the latter, actors with non-exclusive ties need to wedge apart the bonds between the imperial core and the external actor. Actors with both weak and non-exclusive ties need to engage

(2011); Stacie E. Goddard, 'Embedded revisionism: Networks, institutions, and challenges to world order', International Organization, 72:4 (2018).

${ }^{13}$ Daniel H. Nexon, The Struggle for Power in Early Modern Europe: Religious Conflict, Dynastic Empires, and International Change (Princeton: Princeton University Press, 2009); Nexon and Wright, 'What's at stake in the American empire debate'; Paul K. MacDonald, Networks of Domination: The Social Foundations of Peripheral Conquest in International Politics (New York, NY: Oxford University Press, 2014); Paul K. MacDonald, 'Embedded authority: A relational network approach to hierarchy in world politics', Review of International Studies, 44:1 (2018); Jeppe Mulich, 'Microregionalism and intercolonial relations: The case of the Danish West Indies, 1730-1830', Journal of Global History, 8:1 (2013); Jeppe Mulich, 'Transformations at the margins: Imperial expansion and systemic change in world politics', Review of International Studies, 44:4 (2018); Andersen, 'Semi-cores in imperial relations'.

${ }^{14}$ Alexander J. Motyl, Imperial Ends: The Decay, Collapse, and Revival of Empires (New York: Columbia University Press, 2001), p. 17; Nexon, The Struggle for Power in Early Modern Europe, p. 132.

${ }^{15}$ Mulich, 'Microregionalism and intercolonial relations'.

${ }^{16}$ MacDonald, Networks of Domination, p. 49.

${ }^{17}$ Ibid., p. 7; Nexon and Wright, 'What's at stake in the American empire debate', p. 260. 
both strategies. As such, strategies to acquire external support follow different logics, varying ideal-typically - between logics of integration and logics of fragmentation. ${ }^{18}$

These arguments will be fleshed out in three parts. First, I will make the case that extraimperial ties have largely been neglected in relational studies of empires and their conceptualisations of peripheral power. In the second part of the article I develop a theoretical framework in which both the various positions, as well as the strategies that arise from them, are conceptualised. Lastly, I will probe the utility of this theoretical framework by analysing two case studies: the American Revolution and the Angolan War of Independence. ${ }^{19}$

\section{Sources of peripheral positional power}

Empires consist of relations. The most common way to conceptualise imperial relations is through the concepts of 'core' and 'periphery'. ${ }^{20}$ With the revival of the study of empires in IR, scholars have made the relational character of empires more explicit. Daniel Nexon and Thomas Wright, for instance, note the difficulty in defining empires with the use of categorical attributes. Rather, they conceptualise empires as relational-structural arrangements 'that vary in terms of their network properties' ${ }^{21}$ The core and the periphery in an empire are in this example nodes in a network structure, and the power each node has depends on its position within the network itself. The ability of the core to mobilise resources across the network is significantly shaped by their position within broader social networks'. ${ }^{22}$ As such, rather than conceptualising power according to realist logics of relative material power, network theorists argue for the centrality of relative positional power. ${ }^{23}$

By reviewing the literature on empires, this section argues that scholars of empire have located three positional dimensions in which peripheral power is found: on the shifting ties between core and periphery, ties within the peripheral unit itself, and ties between peripheral units. In the following sections of the article, I will build on their relational conception of empire to locate a fourth dimension of peripheral power: ties with extra-imperial actors.

\section{Core and periphery}

As imperial peripheries are under the hierarchical rule from a metropolitan power, variations in the strength of these hierarchical ties are often thought to give peripheral actors more or less power to act autonomously. In hierarchical systems, '[s]ome are entitled to command; others are required to obey. ${ }^{24}$ David Lake, for instance, argues that 'hierarchy exists when one actor, the ruler ... possess authority over a second actor, the ruled'. ${ }^{25}$ The ruled, in other words, have little capacity to act autonomously. Their domestic and foreign policies are dictated by dominant states. $^{26}$

This form of hierarchical rule is prevalent in empires. An empire consists, according to Michael Doyle, of 'a relationship, formal or informal, in which one state controls the effective

\footnotetext{
${ }^{18}$ Goddard and Nexon, 'The dynamics of global power politics', p. 8 .

${ }^{19}$ As such, the framework will not be tested in any formal way. Rather, the aim is, as Levy notes regarding plausibility probes, to 'give the reader a "feel" for a theoretical argument by providing a concrete example of its application, or to demonstrate the empirical relevance of a theoretical proposition by identifying at least one relevant case.' Jack S. Levy, 'Case studies: Types, designs, and logics of inference', Conflict Management and Peace Science, 25:1 (2008), pp. 6-7.

${ }^{20}$ Johan Galtung, 'A structural theory of imperialism', Journal of Peace Research, 8:2 (1971), p. 81.

${ }^{21}$ Nexon and Wright, 'What's at stake in the American empire debate', p. 255.

${ }^{22}$ MacDonald, 'Embedded authority', p. 16.

${ }^{23}$ Hafner-Burton and Montgomery, 'Power positions', p. 4.

${ }^{24}$ Kenneth N. Waltz, Theory of International Politics (New York: Random House, 1979), p. 88.

${ }^{25}$ David A. Lake, Hierarchy in International Politics (Ithaca: Cornell University Press, 2009), p. 51.

${ }^{26}$ MacDonald, 'Embedded authority', p. 6.
} 
political sovereignty of another political society. ${ }^{27}$ Similarly, in Lake's definition, 'one partner cedes substantial rights of residual control directly to the other; in this way the two polities are melded together in a political relationship in which one partner controls the other'. ${ }^{28}$ In empires, thus, direct or indirect hierarchical ties flow from cores to peripheries. ${ }^{29}$ Whether directly or indirectly ruled, the capacity of each peripheral actor to act autonomously depends on variations in the hierarchical ties between core and periphery.

This view is perhaps most explicit in David Lake's continuum of security relations, in which dyads can at one extreme be an alliance and at the other an empire. ${ }^{30}$ Alliances are, according to Lake, anarchic relationships; imperial relations are hierarchical. The two middle categories in Lake's spectrum - protectorate and informal empire - are defined as more hierarchical than alliances and less hierarchical than empire. Equally, one might think of variance on the coreperiphery spectrum in terms of the quality of relationship between the two parties. For Immanuel Wallerstein, for instance, 'semi-peripheries' are peripheries that have more core-like features than the other peripheral units. ${ }^{31}$ Andersen theorises, in a similar vein, the category of 'semi-cores', which 'while part of the overall imperial structure, is differentiated by being closer to the core'. ${ }^{32}$ As such, the capacity for peripheries to act autonomously increases when their ties become more horizontally structured: a protectorate has more autonomy than a peripheral unit in an informal empire; a peripheral unit has less autonomy than a semi-core or semi-periphery in a formal empire. Thus, the variations of ties between a core and a peripheral unit change the latter's positional power within the imperial structure.

\section{Local ties}

While such an approach only negatively defines peripheral positional power - as the varying degrees of freedom from rule by the core - there are a number of theorists who argue that peripheral capacity emanates from within the periphery itself. Andrew Mack, for instance, examines why militarily weak colonies were able to secede from much stronger metropoles. Rather than winning militarily, colonies achieved secession 'from the progressive attrition of their opponents' political capability to wage war. ${ }^{33}$ A key part of peripheral success, Mack argues, was their stronger will. Others have argued that it has less to do with peripheral resolve than with strategy. ${ }^{34}$ In fact, strategies such as guerilla warfare are designed to break down the opponents' resolve. With better local knowledge than the opponent, the periphery can deploy strategies that tear down the enemy's will to wage war.

In order to successfully employ strategies that can wear down a militarily stronger opponent, the population in the periphery needs to mobilise across local segments. MacDonald highlights that, in order to fight off a foreign conqueror, there needs to be collaboration among different

\footnotetext{
${ }^{27}$ Doyle, Empires, p. 45.

${ }^{28}$ David A. Lake, 'Anarchy, hierarchy, and the variety of international relations', International Organization, 50:1 (1996), p. 34 .

${ }^{29}$ Empires are also ruled indirectly, through intermediaries who 'enjoy considerable autonomy within their own domains'. Charles Tilly, 'How empires end', in Karen Barkey and Mark von Hagen (eds), After Empire: Multiethnic Societies and Nation-Building (New York: Routledge, 1997), p. 3. On indirect rule in empires, see also Nexon and Wright, 'What's at stake in the American empire debate', pp. 258-9. On the distinction between direct and indirect rule, see John Gerring, Daniel Ziblatt, Johan Van Gorp, and Julian Arevalo, 'An institutional theory of direct and indirect rule', World Politics, 63:3 (2011).

${ }^{30}$ Lake, 'Anarchy, hierarchy, and the variety of international relations', p. 7.

${ }^{31}$ Immanuel Wallerstein, 'Semi-peripheral countries and the contemporary world crisis', Theory and Society, 3:4 (1976), p. 463 .

${ }^{32}$ Andersen, 'Semi-cores in imperial relations', p. 190.

${ }^{33}$ Andrew Mack, 'Why big nations lose small wars: The politics of asymmetric conflict', World Politics, 27:2 (1975), p. 177, emphasis in original.

${ }^{34}$ Ivan Arreguin-Toft, How the Weak Win Wars: A Theory of Asymmetric Conflict (New York: Cambridge University Press, 2005).
} 
peripheral elites. ${ }^{35}$ Thus, the more integrated these elites are, collective action problems are more easily overcome, and conquerors will find it more difficult to divide and conquer the population. ${ }^{36}$ As a corollary, peripheral polities with sparse ties to the conqueror as well as relatively integrated elites have a greater capacity to undermine imperial rule.

\section{Inter-peripheral ties ${ }^{37}$}

While strong ties between different segments of the local population increase a peripheral unit's collective mobilisation capacity, so do social ties between peripheral polities within the same imperial structure. As Nexon argues, dense social ties between peripheries in the same empire 'undermine the institutional basis of divide-and-rule in star-shaped political systems' ${ }^{38}$ This is demonstrated, Karen Barkey notes, by 'how actively the Ottoman State, for example, fought the increasing connectivity and alliances between peripheral groups such as the nomads and the local notables in the eighteenth century'. ${ }^{39}$ When these divide-and-rule strategies fail, however, peripheral units are able to wage significant powers against the core. This is what happened when the 13 British colonies in North America succeeded from the British Empire. As Motyl argues, 'because Britain's American colonies had developed extensive economic and political linkages long before 1776, they could mount organized opposition to His Majesty's imposition of various taxes and successfully rebel'. ${ }^{40}$

The peripheral capacity for autonomous collective action, thus, is not only defined negatively as the freedom from hierarchical rule from a metropolitan power. Rather, specific local ties either inside one peripheral unit or between peripheral units, and their abilities to forge ties, are what specify peripheral positional power. But as has been argued above, and which will be explored in more detail below, the 13 North American colonies mobilised not only inside and between individual colonies; they also engaged in international politics by mobilising external actors for their decolonial struggles. These extra-imperial ties - the fourth dimension of peripheral positional power ties - I argue, should complement the other three reviewed here.

\section{Extra-imperial ties and collective mobilisation}

When imperial peripheries develop relations to actors outside the imperial structure, they form extra-imperial ties. These external actors vary, of course, in size and power. Some are peripheries in another empire; others are great powers. Material power is undoubtedly salient since mobilising a great power means that, theoretically, more power can be mobilised against the imperial core. But, as I will argue in this section, by paying attention to the quality of the ties to the external actor we can more easily see how ties to a small power or an imperial periphery can, depending on the structure of the ties, increase the peripheral positional power more than ties to a great power. To this end, I propose that we should pay attention to two key qualities of these forms of social ties: density and exclusivity. The logic behind this is that dense social ties with an external actor makes the latter more likely to be mobilised. However, in order for peripheries to acquire long-term support, dense social ties are not always sufficient. The core can engage in divide-and-rule strategies whereby the external party is either coerced or compelled to break its alliance with the peripheral unit. Conversely, exclusive ties between the peripheral unit and the external

\footnotetext{
${ }^{35}$ MacDonald, Networks of Domination, pp. 46-77.

${ }^{36}$ On divide and conquer, see also Victoria Tin-bor Hui, 'Towards a dynamic theory of international politics: Insights from comparing Ancient China and early modern Europe', International Organization, 58:1 (2004), p. 180.

${ }^{37}$ Inter-peripheral ties refer here to ties between peripheries in the same imperial structure, not ties to all peripheral actors.

${ }^{38}$ Nexon, The Struggle for Power in Early Modern Europe, p. 109.

${ }^{39}$ Karen Barkey, Empire of Difference: The Ottomans in Comparative Perspective (Cambridge: Cambridge University Press, 2008), p. 10.

${ }^{40}$ Motyl, Imperial Ends, p. 137.
} 
actor - meaning that the core has no or only sparse ties to the external actor - make it more difficult for the centre to engage in wedge strategies to break up the alliance. In the following, I will first present these two qualities more thoroughly, then argue that certain mobilisation strategies arise from the variations in these two qualities.

\section{Density}

The density of social ties is a key measurement in network analyses. 'Any relatively durable transaction', Nexon argues, 'such as economic exchange, ongoing communication, coercion, and alliance, produces social ties. ${ }^{\prime 1}$ As such, social ties have both form and content: 'they include "real" material transactions, such as alliances and trade transactions, as well as ideational relations, such as narratives and repertoires that define appropriate behavior, legitimate authority, and give meaning to behavior in world politics. ${ }^{42}$ The social ties have, in other words, a pattern or a structure to them (form) - such as dyads or triads - and through these structures flow meanings that are attached to the ties (content). ${ }^{43}$

Social ties can, moreover, vary in terms of character or quality. Dense or strong ties are thus analytically separated from weak or sparse ties. Sparse ties are 'exchanges that are rare, unimportant, unidirectional, and fleeting'. Dense ties, in contrast, are 'exchanges that are large in magnitude, reciprocal in character, and frequent and sustained over time'. ${ }^{44}$ The variations in this quality of social ties have implications for theories of international relations. Alliances as conceptualised in neorealism, for instance, always consist of weak ties. 'In a multipolar system', Glenn Snyder argues, 'alliances are never absolutely firm, whatever the text of the written agreement; therefore, the fear of being abandoned by one's ally is ever present. ${ }^{45}$ In contrast, alliances with dense social ties 'facilitate monitoring and other nuts-and-bolts components of joint-action'. ${ }^{46}$ As such, collective mobilisation becomes more or less difficult depending on the strength of the ties that link two nodes in a network.

These qualitative distinctions are important for the relational study of empire. In order to maintain hierarchy in empires, the core needs to make sure the dense, hierarchical ties between it and the periphery persist, while also using various measures to avoid inter-peripheral integration. ${ }^{47}$ Imperial cores derive their authority from the central position they inhabit in the imperial structure. ${ }^{48}$ All peripheries are tied to it, but they are not tied or only sparsely tied to each other; all inter-peripheral communication must go through the core. Thus, the core holds a key brokerage position. ${ }^{49}$

This, I wager, should also include ties to units external to the empire. When imperial peripheries form dense ties with external actors, they undermine the central strategy of imperial rule: divide-and-rule. Once peripheries form ties to actors other than the core, they are no longer isolated, and can use these ties to mobilise significant forces against the core. In the framework presented below, the periphery is depicted as a unitary actor. This is only an analytical simplification, however, due to the fact that one peripheral actor can be split into different factions, each having different degrees of density with an external actor. Whether the peripheral actor is unified or fragmented, as we shall see, can have a bearing on their ability to mobilise actors outside the imperial structure.

\footnotetext{
${ }^{41}$ Nexon, The Struggle for Power in Early Modern Europe, p. 42.

${ }^{42}$ Goddard, 'Embedded revisionism', p. 767.

${ }^{43}$ Emily Erikson, 'Formalist and relationalist theory in social network analysis', Sociological Theory, 31:3 (2013).

${ }^{44}$ MacDonald, Networks of Domination, p. 49.

${ }^{45}$ Glenn H. Snyder, 'The security dilemma in alliance politics', World Politics, 36:4 (1984), p. 466

${ }^{46}$ Nexon, The Struggle for Power in Early Modern Europe, p. 50.

${ }^{47}$ Nexon and Wright, 'What's at stake in the American empire debate', p. 260.

${ }^{48}$ MacDonald, 'Embedded authority', p. 16.

${ }^{49}$ Nexon and Wright, 'What's at stake in the American empire debate', p. 260; Galtung, 'A structural theory of imperialism', p. 90.
} 
Density of social ties has been, in the literature on empires, crucial in explaining peripheral power; both when such ties are intra-peripheral or inter-peripheral. In this way, the proposed framework to understand the significant role external actors play in imperial dynamics does not significantly diverge from previous theorisations. In order for collective action to sustain, peripheral actors need to form dense ties with external actors. But, as Stacie Goddard notes, actors cannot build relations at will, as other actors - in this case, the imperial core - might deny them access to institutionalised networks. ${ }^{50}$ This is the key argument for why a second variable of peripheral positional power is needed.

\section{Exclusivity}

When a peripheral actor forges ties to an external actor to which the core only has a weak relationship, if even connected at all, I will here treat it as having established an exclusive relationship. Of course, this relationship is not exclusive in any real sense of the word; rarely do we find, especially in our globalised world, political actors who are completely unconnected. The concept of 'exclusivity' as used here is thus an ideal type, a deliberate simplification of reality. But, I argue, it is a simplification that has analytical purchase. And, as an ideal-typical concept, the analytical purchase should be evaluated, not based on the accuracy with which it describes empirical reality, but whether or not it assists us in making sense of complex relationships between a set of actors. ${ }^{51}$

Once imperial peripheries forge exclusive ties to an external actor, it upsets both the structure and the logic of rule in empires. The structure of an empire is ideal-typically such that the peripheral nodes are altogether disconnected from one another and from external actors, and thus remain exclusively tied to the core. It is from this position of brokerage that the core ultimately derives its power. ${ }^{52}$ It has 'exclusive ties to otherwise marginalized or weakly connected nodes or group of nodes', and it turns this position into social power by bridging structural holes in the network. ${ }^{53}$ Because the peripheral units have no exclusive ties to any actors, they are in a precarious position. As we have seen above, once peripheral units within the same imperial structure form dense ties between them, they improve their position significantly by being able to mobilise resources across the intra-imperial network. But the dense ties they form between them are nevertheless not exclusive; the core still maintains its central role in the network, although it has lost its position as a broker, and can as such still engage in fragmenting strategies to wedge apart any emerging ties between the peripheries.

If the peripheral unit, on the other hand, can reach outside the imperial structure, and form ties with an external actor, not only does the core lose its position as broker, its capacity for engaging in fragmenting strategies will ultimately depend on whether the core itself possesses some ties to that external actor. The absence of such ties means that the ties between the peripheral unit and the external actor are exclusive. If a peripheral actor has, ideal-typically, nonexclusive ties to an external actor, I argue, the core can still pursue fragmenting strategies to undermine the extra-imperial collective mobilisation. One such strategy is 'wedging', utilised when the goal is 'to prevent, break up, or weaken a threatening or blocking alliance at an acceptable cost'. ${ }^{54}$ This is done either by using 'concessions and other inducements to lure a target away from other adversaries', 55 or by using coercive measures to expose weakness in the bonds within

\footnotetext{
${ }^{50}$ Goddard, 'Embedded revisionism', p. 769.

${ }^{51}$ Concepts, as Weber argued, cannot be 'ideational reproductions of "objective" reality', but are necessarily 'theoretical means for the purpose of intellectual mastery of the empirically given'. Max Weber, Max Weber: Collected Methodological Writings (Abingdon: Routledge, 2012), pp. 134-5.

${ }^{52}$ On brokerage, see Goddard, 'Embedded revisionism', pp. 771-2; Carpenter, 'Vetting the advocacy agenda', p. 75.

${ }^{53}$ Hafner-Burton, Kahler, and Montgomery, 'Network analysis for international relations', p. 571.

${ }^{54}$ Timothy W. Crawford, 'Preventing enemy coalitions: How wedge strategies shape power politics', International Security, $35: 4$ (2011), p. 156

${ }^{55}$ Ibid., p. 158.
} 
the enemy coalition. ${ }^{56}$ Whether using carrots or sticks, an imperial core with significant ties to the external actor can use this position to wedge apart any developing relations between the latter and a peripheral actor.

Peripheral actors with exclusive ties, in contrast, do not run these risks. In such a scenario, it is the imperial core that is suddenly in a vulnerable position. It has less leverage to fragment any forming ties between the imperial periphery and the external actor, and is often left with the single option to use, or to threat to use, military force. As such, exclusive ties to an external actor subvert the divide-and-rule strategy that is central to imperial rule. Due to the vulnerable position in which this places the core, exclusive ties to a 'lesser' power might prove to be more salient for collective mobilisation against an imperial core than non-exclusive ties to a great power.

\section{The enemy of my enemy is my friend}

By using the two relational categories of density and exclusivity, we can create four ideal-typical network positions in which peripheral units are located: dense and exclusive, dense and nonexclusive, weak and exclusive, and weak and non-exclusive. These four network positions are depicted in Figure 1. Peripheral actors with dense and exclusive ties to an external actor inhabit a position from which they can wage significant power against the core. Theoretically, such a peripheral unit is most likely to mobilise external actors for their cause. Conversely, a peripheral actor with weak and non-exclusive ties to an external actor is in a structurally weak position. The external actor has ties to the imperial core, and significant efforts by the imperial periphery are needed both to strengthen the ties to an external actor and make sure that the ties between the external actor and the core do not remain strong.

These efforts and strategies are important to conceptualise. Here, I make the argument that, from the varying network structures in which peripheral units find themselves, we can analytically isolate certain key strategies. It will follow the two broad, ideal-typical logics of fragmentation and integration. ${ }^{57}$ In order to mobilise an external actor, actors with weak ties need to engage in integrative strategies such as binding. ${ }^{58}$ However, in order to mobilise an external actor to which it as non-exclusive ties, it is forced to go beyond integrative strategies; it also needs to disrupt ties flowing from one node to another by the use of fragmenting strategies, such as the abovementioned wedging strategy. From the four ideal-typical positions of peripheral units, we can thus specify some key strategies that are likely to be engaged.

Dense and exclusive. Peripheral units that have both dense and exclusive ties to an external actor have a high capacity to mobilise forces against the core. They will draw on these ties to acquire the support of the external actor. The most important strategy they can employ is that of patience. If coercive strategies, such as posing ultimatums, are made to force the hand of the external actor, one might risk pushing the latter away.

Weak and exclusive. When ties to the external actor are weak and exclusive, the peripheral unit needs to engage in binding strategies. Binding strategies can take many forms: diplomatic, economic, or cultural. ${ }^{59}$ Because ties are weak or sparse, the peripheral unit will 'attempt to maintain or enhance an ally's loyalty to their alliance'. ${ }^{60}$ It needs to 'constrain or enmesh targets in

\footnotetext{
${ }^{56}$ Yasuhiro Izumikawa, 'To coerce or reward? Theorizing wedge strategies in alliance politics', Security Studies, 22:3 (2013), p. 503.

${ }^{57}$ On these two logics and the strategies, such as binding and wedging, that follow these logics, see Goddard and Nexon, 'The dynamics of global power politics', p. 8.

${ }^{58}$ On binding strategies, see G. John Ikenberry, After Victory: Institutions, Strategic Restraint, and the Rebuilidng of Order after Major Wars (Princeton: Princeton University Press, 2001), p. 41; Goddard and Nexon, 'The dynamics of global power politics', p. 9.

${ }^{59}$ Goddard and Nexon, 'The dynamics of global power politics', p. 9; Ikenberry, After Victory, p. 41.

${ }^{60}$ Yasuhiro Izumikawa, 'Binding strategies in alliance politics: The Soviet-Japanese-US diplomatic tug of war in the mid-1950s', International Studies Quarterly, 62:1 (2018), p. 110.
} 


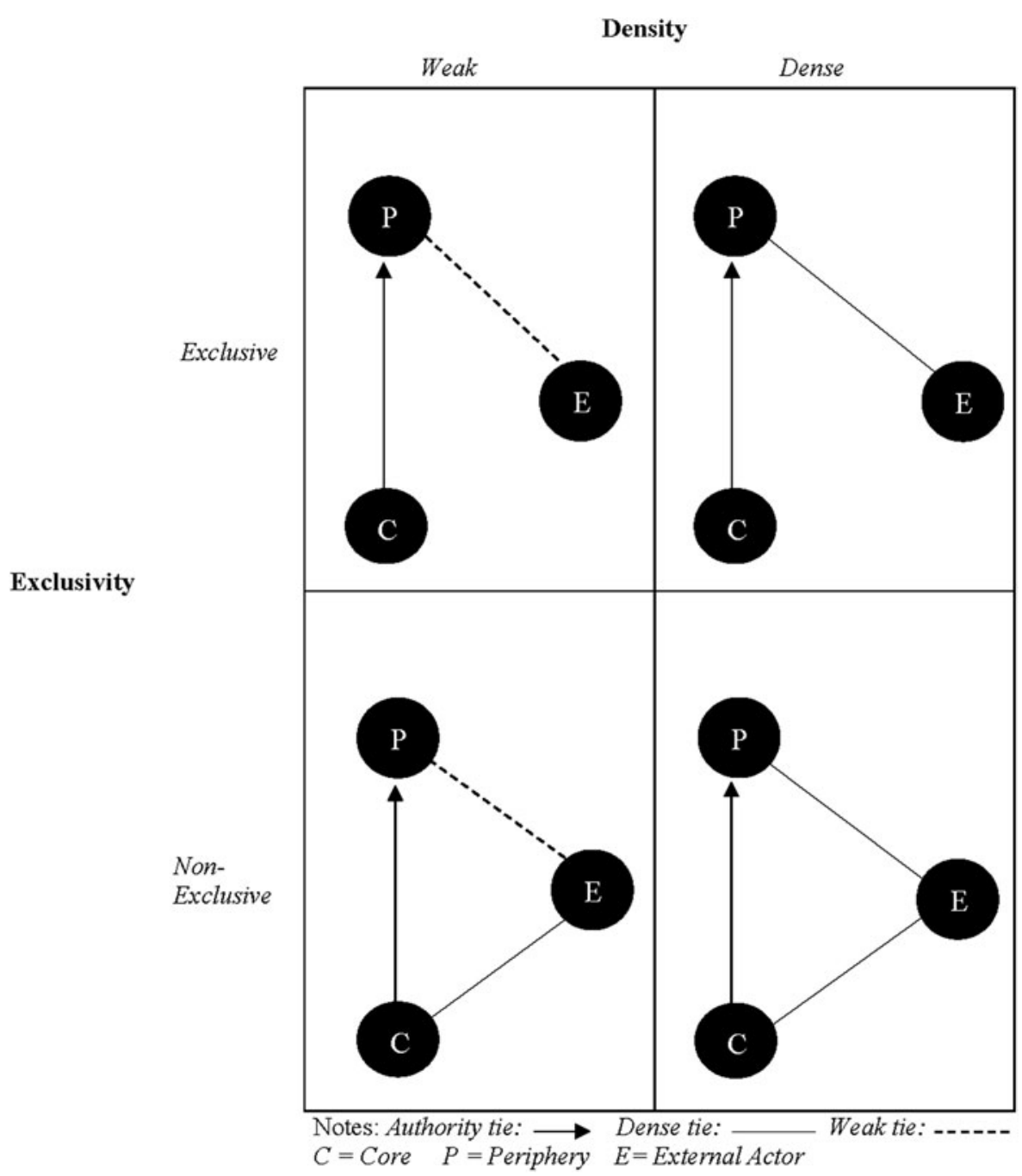

Figure 1. Peripheral positional power.

institutions, agreements, or forms of interdependency so as to weaken their ability to pursue autonomous policies' ${ }^{61}$ Binding strategies can be based on either positive or negative sanctions. ${ }^{62}$ Due to its exclusive ties to an external actor, it is unlikely that it will use coercive strategies, with the risk of pushing away an ally. It will thus seek to compel the external actor to form stronger ties, by, for instance, giving the external actor exclusive access to its commercial markets. As illustrated below, the American Revolutionaries used concessions as binding strategies to attract the support of France and Spain.

Weak and non-exclusive. Peripheral units with weak and non-exclusive ties have little capacity to act. As they have only weak ties to the external actor, they need, like all actors with weak ties, to forge ties. As such, they will engage in binding strategies. But these efforts might be cut off due to the peripheral actor's non-exclusive relationship to the external actor. For this reason, they also

\footnotetext{
${ }^{61}$ Daniel H. Nexon, 'Review: The balance of power in the balance', World Politics, 61:2 (2009), p. 346.

${ }^{62}$ Izumikawa, 'Binding strategies in alliance politics', p. 110.
} 
need to drive a wedge between the external actor and the core. The strategies, thus, need to involve logics of both fragmentation and integration. First, due to their weak position, binding strategies need to be more radical than that of peripheries in a weak but exclusive position. One such strategy can be to give up parts of their autonomy by offering 'military bases or the coordination of foreign and domestic policies, that can increase [the] stronger ally's freedom of action while increasing their protection from external threats'. ${ }^{63}$

Second, they can engage in a 'pincer movement' strategy. ${ }^{64}$ By engaging in this strategy, the peripheral unit seeks to coerce the external actor into breaking the alliance with the core by forming ties with one or more of the external actor's enemies. As such, it will pressure the external actor on the flanks, as it were, hoping this pressure will force it to change its policies. Both of these coercive strategies, however, are risky. As the British foreign secretary, George Canning, argued after he discovered that the members of the diplomatic mission from Rio de la Plata (now Argentina), sent to Britain to acquire support for their independence struggles, were also meeting with the French: 'It must be obvious ... that no satisfactory relations could possibly exist between His Majesty's Government and by any individual, however eminent, who should be accredited at the same time both to this country and to France. ${ }^{65}$ But due to their precarious position, peripheral units are often pressured to take such risks. They need to engage radical strategies in order to strengthen ties to external actors and drive a wedge between the external actor and the imperial core.

Dense and non-exclusive. Peripheries in this position need also to engage fragmentary strategies, but less coercive than actors with only weak ties to an external actor. One such strategy is what Nexon terms 'multi-vocal signaling'. ${ }^{66}$ By engaging in such strategies, different identities are projected to different audiences in order to put pressure on an external actor, but less so than in a pincer-movement scenario. During the Cold War, for instance, the Algerians 'knew that the United States, in particular, would never allow North Africa to pass under Soviet influence'. ${ }^{67}$ But as an ally of France, they also knew that the Americans would never formally ally with them. In order to acquire American support, then, the Algerians could exploit the US-Soviet rivalry to their favour. By holding the door open to Soviet support, while at the same time claiming to the Americans that they had closed the door to the communists, they hoped the former would secure an alliance with the communist states, and that the latter would, at least, make the American support for the French colonial regime wane. As one report regarding their diplomatic strategy stated: 'When we intend to put on our side of the scale an act of support from a Socialist country we will think at the same time of removing from the colonial side of the scale the weight of Western support. ${ }^{68}$

Taken together, the different combinations of density and exclusivity have crucial influences on the strategies adopted. Actors with weak and exclusive ties need to engage in binding strategies; actors with dense and non-exclusive ties need to engage in wedging strategies. But due to their relatively well-placed position, they do not need to go to the same lengths as an actor with both weak and non-exclusive ties: oftentimes their strategies will not involve coercive elements due to the inherent risk in scaring away an ally or scaring a potential ally into the arms of the imperial core. Next, I will demonstrate how the Americans' weak and exclusive position

\footnotetext{
${ }^{63}$ James D. Morrow, 'Alliances and asymmetry: An alternative to the capability aggregation model of alliances', American Journal of Political Science, 35:4 (1991), p. 905.

${ }^{64}$ See Andersen for an example of how pincer-movement tactics are used in the formation of imperial relations. Morten Skumsrud Andersen, How Empires Emerge (Oslo: NUPI, 2011), pp. 31-4.

${ }^{65}$ Klaus Gallo, Great Britain and Argentina: From Invasion to Recognition, 1806-26 (New York: Palgrave, 2001), pp. 158-9.

${ }^{66}$ Nexon, The Struggle for Power in Early Modern Europe, pp. 99-100.

${ }^{67}$ Matthew Connelly, 'Rethinking the Cold War and decolonization: The grand strategy of the Algerian War for independence', International Journal of Middle East Studies, 33:2 (2001), p. 223.

${ }^{68}$ As quoted in ibid., p. 223.
} 
influenced the diplomatic strategies adopted in acquiring French assistance during the American Revolutionary War.

\section{The American Revolutionary War}

A decade-long transformation led 13 British colonies in North America to become a federated sovereign state. A critical juncture in this process was when the Americans began receiving support from France and Spain. While the insurgents ran successful military campaigns against the British 'red coats' they 'lacked the power to move the war from stalemate to decisive victory'. ${ }^{69}$ The decisive moments came when France entered the war in 1777 and when a formal Franco-American alliance was established the following year. As concluded by Samuel Flagg Bemis: 'The French Alliance, let it never be forgotten, brought independence'. ${ }^{70}$ Robert Hager and David Lake see France's entrance into the intra-imperial war as a balancing effort. As the British emerged victorious from the Seven Years' War, and was, generally, the rising power in Europe, the French 'feared for its position in the European system'. 'B1 'Balance of power politics', they argue, 'was central to France's decision to intervene in the colonial revolt'. ${ }^{2}$

It is difficult, however, to speak of motives. For example, Bemis, the diplomatic historian whose narrative is central to the argument of Hager and Lake, argues that what primarily drove French foreign policy from 1763 to 1783 was a lust for revenge. ${ }^{73}$ To analyse whether the French were driven by an emotional desire for revenge or a rational idea of weakening an ascending Britain, is not the ambition of the following section. Instead, it will demonstrate that the structure of the international networks in the 1770s significantly favoured the Americans, vis-à-vis both Britain and France.

Against Britain, the Americans benefited greatly from the former's isolation from the alliance networks of the continent. If Britain was allied to France - and, as we shall see, only a few years before the American Revolution, it nearly was - this would have made it a lot easier for the British to use fragmenting strategies to drive a wedge in between an emerging French-American alliance. Of course, this did not mean that Britain had no ties to France, and that the latter's relationship to the Americans was completely exclusive. But, as I will argue, had a rapprochement between France and Britain occurred in the 1770s, Britain would have been in a much better position to wedge apart an emerging Franco-American alliance.

Against France, the Americans could use their emerging ties to the French to play the two European foes against each other. By using binding strategies to form denser ties with France, the Americans were in a position from which they could pressure the former by signalling that they might strike a deal with Britain and form an alliance against the two Bourbon powers. The Americans, in other words, were not only in a pole position to mobilise external actors; they were also in a position in which successful mobilisation would likely result in a sustained effort from the external actor to secure the Americans' secession from the British Empire.

\section{The splendid isolationist}

As Alexander J. Motyl has argued, extensive economic and political ties between the North American colonies allowed for successful inter-peripheral mobilisation. ${ }^{74}$ Yet, as we have seen,

\footnotetext{
${ }^{69}$ Record, 'External assistance', p. 39.

${ }^{70}$ Samuel F. Bemis, The Diplomacy of the American Revolution (Bloomington: Indiana University Press, 1957), p. 255.

${ }^{71}$ Robert Hager and David A. Lake, 'Balancing empires: Competitive decolonization in international politics', Security Studies, 9:3 (2000), p. 122.

${ }^{72}$ Ibid.

${ }^{73}$ Bemis, The Diplomacy of the American Revolution, p. 16.

${ }^{74}$ Motyl, Imperial Ends, p. 54. See also, Alan Tully, 'The political development of the colonies after the Glorious Revolution', in Jack P. Greene and J. R. Pole (eds), A Companion to the American Revolution (Malden: Blackwell Publishers, 2000), p. 29.
} 
as the imperial core inhabits a central position within the imperial network, with ties to all peripheral actors, inter-peripheral alliances can easily be fragmented by the imperial core by the use of wedging strategies. Thus, I have argued, successfully mobilising external actors in this way places peripheral actors in a much stronger position. But for this to be the case, the external actor cannot have any significant ties to the imperial core; otherwise, such an alliance would be as precarious as an inter-peripheral alliance.

Britain, however, operated in the period 1762-87 in splendid isolation from European alliance networks. ${ }^{75}$ This did not mean that it was completely isolated; it still maintained longstanding ties to both Portugal and the United Provinces of the Netherlands. Yet, these ties proved variably successful in hindering the two from lending support to the Americans. While Portugal was the first European state to suspend trade with the colonists, compelling the United Provinces to do the same proved to be more difficult. Anglo-Dutch ties had weakened through a series of events in the latter half of the eighteenth century; among them the Stadtholder's marriage to an anti-English Prussian, British hard-hand approach to restrictions on Dutch trade, and an erratic British ambassador in The Hague. ${ }^{76}$ Even if Britain believed the United Provinces to be a client state, and it was able to use its ties to the Dutch to force the latter to condemn the export of munitions to the Americans from St Eustatius, a Dutch colony in the Caribbean, it was never able to stop this trade altogether. ${ }^{77}$

If severing ties to the Dutch had consequences for British influence, the weak ties to the Bourbon powers left Britain completely unable to compel or coerce neither France nor Spain to suspend their support to the Americans. The only option left was to make war on the Bourbon powers, and this was a war no British minister wanted. ${ }^{78}$ Britain's position, however, could have been radically different. In the early 1770s, Austria, Prussia, and Russia took more control over the management of European affairs, which disturbed France. Consequently, France reached out to Britain for a surprising alliance between the old foes. Such an alliance, France was convinced, 'was the most promising way to restore France's vanishing influence in Europe'. ${ }^{79}$

However, the British response - which was one of 'caution and inaction' - made the French olive branch amount to nothing. ${ }^{80} \mathrm{Had}$ such an alliance been signed, and the diplomatic rapprochement between the two enemies fulfilled, the Americans would have been in a very different position when searching for support than they ended up being. In this counterfactual scenario, although it might still have been in France's interests to weaken Britain, France would also have been reliant upon the British to contain the influence of the 'eastern powers' on the affairs of the continent. By threatening to depart from Anglo-French cooperation, and thus leave the French alone in balancing against these powers, Britain could have wedged apart the Americans and the French by making it the latter's interest not to support the former. In fact, as Paul Mapp argues, the French foreign minister's main goal of weakening Britain was not to 'abase a colonial rival', but rather to 'chasten and diminish it so that Britain would be more receptive to working in partnership with France to stabilize Europe, as the two powers had done during a period of warm relations in the 1720 s and $1730 s^{\prime} .{ }^{81}$

\footnotetext{
${ }^{75}$ Jeremy Black, 'Britain's foreign alliances in the eighteenth century', Albion: A Quarterly Journal Concerned with British Studies, 20:4 (1988), p. 577.

${ }^{76}$ H. M. Scott, British Foreign Policy in the Age of the American Revolution (Oxford: Clarendon Press, 1990), pp. $225,231$.

${ }^{77}$ J. Franklin Jameson, 'St. Eustatius in the American Revolution', The American Historical Review, 8:4 (1903).

${ }^{78}$ Scott, British Foreign Policy in the Age of the American Revolution, p. 243.

${ }^{79}$ Ibid., p. 166.

${ }^{80}$ Jeremy Black, Natural and Necessary Enemies: Anglo-French Relations in the Eighteenth Century (London: Duckworth, 1986), p. 76.

${ }^{81}$ Paul W. Mapp, 'The Revolutionary War and Europe's great powers', in Jane Kamensky and Edward G. Gray (eds), The Oxford Handbook of the American Revolution (New York: Oxford University Press, 2012), p. 317.
} 
Britain's position in Europe, therefore, significantly impacted the positional power of the Americans. Due to Britain's weak ties to the continent, it was walking a tightrope: in order to avoid a war with France, Britain was initially forced to overlook the French aid provided to the Americans. ${ }^{82}$ The Americans were, as such, in a position from which they more freely could form ties to the French. While French support might have been preordained, due to the French need to balance against Britain, such support, I have argued, would have been more costly to the French had they been dependent on British support to balance against the 'eastern' influence over the affairs of the continent.

\section{American diplomacy}

Had an Anglo-French alliance been signed in 1772, this would have put the American agents in Europe, among them Benjamin Franklin, who had been sent to France to secure an alliance, in a very difficult situation. Not only would they need to mobilise these powers to spend a great deal of material resources to assist the Americans in their military struggles; they would also need to convince them to sever their ties to Britain and all the benefits that could be drawn from this relationship. But as the Anglo-French rapprochement amounted to nothing, there were no strong ties the Americans needed to wedge apart; Franklin's sole task was to convince the French that this was a war worth fighting.

While it might have been in the French interests to weaken Britain, it was nevertheless not a given that France should choose to fight this war. Vergennes, the French foreign minister was not immediately convinced the Americans would win a war against Britain; he was unsure if Spain would assist France in such a war; and he, the other French ministers, and the king were 'uncomfortably aware' of the state of the French navy and finances. ${ }^{83}$ What seems to be universally believed is that the tipping point was the Americans' victory at Saratoga. As David Geggus holds, the 'decision actively to intervene resulted not from Franklin's persuasive diplomacy, but from the assurance brought by the victory at Saratoga that the rebellion would not collapse'. 84

But such an argument neglects the structural environment in which France, Britain, and the Americans operated. While Saratoga might have been crucial in its own sake in convincing the French, it also opened up a diplomatic window for the Americans to pressure France into an alliance. This, I argue, was due to the fact that as the Americans were using various binding strategies to connect stronger ties with France, and as France and Britain remained in hostility, the Americans could use this position of strength to play France and Britain off against each other. As I have explored the second element to this - the lack of ties between France and Britain - in the previous section, I will now turn to the effort made by Franklin and the others to forge this position of strength.

Actors with non-exclusive and weak ties to an external actor, I have argued, need to adopt both wedging and radical binding strategies. The external actor is in such a scenario in a great bargaining position, whether it is in its interests or not to support the peripheral actor. It can draw on its ties to both core and periphery to make sure the best possible deal is struck. In a position of weak but exclusive ties to an external actor, in contrast, the peripheral actor is not constrained as such. The Americans knew that reconciliation between Britain and France was unlikely, but they still needed to make sure the French would commit to fight a war on their behalf. To this end, they adopted numerous binding strategies.

The American colonies and France were loosely tied through trade networks in the Caribbean before the advent of the American Revolution, and these ties were used for the initial contact

\footnotetext{
${ }^{82}$ Scott, British Foreign Policy in the Age of the American Revolution, p. 214.

${ }^{83}$ Ibid., p. 208.

${ }^{84}$ David P. Geggus, 'The effects of the American Revolution on France and its empire', in Greene and Pole (eds), $A$ Companion to the American Revolution, p. 523.
} 
between the Americans and France. ${ }^{85}$ They knew, however, that a diplomatic offensive was needed in order to secure an alliance. ${ }^{86}$ A necessary requirement for such an alliance was American independence. As Richard Henry Lee argued in April 1776: 'no State in Europe will either Treat or Trade with us so long as we consider ourselves Subjects of G[reat] B[ritain]. Honor, dignity, and the customs of states forbid them until we take rank as an independent people. ${ }^{87}$ Merely three months later, on 4 July 1776, the Declaration of Independence was signed. ${ }^{88}$

Three days later, the diplomatic offensive commenced as the American merchant Silas Deane was sent to Paris to negotiate a trade agreement with the French in which the latter would allow the Americans to buy military equipment on credit. ${ }^{89}$ Congress had instructed Deane to sound French intentions and to purchase from the French government uniforms and arms for 25,000 soldiers plus a hundred pieces of field artillery'. ${ }^{90}$ The Americans were also prepared to deepen their relationship with France through a commercial treaty. A specific requirement made to American diplomats negotiating this treaty, was that it 'do[es] not oblige us to become a party in any war which may happen in consequence thereof, and that the immunities, exemptions, privileges, protection, defense and advantages, or the contrary, thereby stipulated, be equal and reciprocal'. ${ }^{91}$ But by December 1776, following a near collapse of the American army, Congress allowed their diplomats to discuss with the French the possibilities for a military alliance. ${ }^{92}$

Peripheries with non-exclusive ties to an external actor need to adopt more coercive measures - such as pincer-movement strategies or multivocal signaling - in order to wedge apart the relationship between the imperial core and the external actor. Actors with exclusive ties, in contrast, are less likely to adopt the stick in the fear of pushing away a potential ally. This has been highlighted as the key success of the initial binding efforts by the Americans: They had, as Jonathan Dull argues, 'refrained from issuing any categorical demands which would have produced a rupture with France. ${ }^{93}$ The Americans were thus, by the time of Saratoga, in a position of strength. Not only had they successfully bound themselves closer to the French, they were also not constrained by a rapprochement in Anglo-French relations. As such, they could use this position to their advantage in order to secure an alliance.

While the American victory at Saratoga proved to the French that the Americans were worth fighting for, it also stimulated a fear in the French foreign minister that the Americans would strike an agreement with Britain, join forces against both France and Spain, and that 'France would have to pay the price of this sacrifice. ${ }^{94}$ Because of their ties to both France and Britain, the Americans could use this to their advantage. While Franklin was aware that the use of coercive strategies - such as making an ultimatum to France, which was suggested by Silas Deane, ${ }^{95}$ - would likely 'make

\footnotetext{
${ }^{85}$ Bemis, The Diplomacy of the American Revolution, p. 34.

${ }^{86}$ On American trade networks prior to the American Revolution, see Richard Pares, Yankees and Creoles: The Trade Between North America and the West Indies before the American Revolution (Cambridge, MA: Harvard University Press, 1956); Dorothy Burne Goebel, 'The "New England trade" and the French West Indies, 1763-1774', The William and Mary Quarterly, 20:3 (1963); Mulich, 'Microregionalism and intercolonial relations', p. 76.

${ }^{87}$ As quoted in David Armitage, 'The Declaration of Independence and international law', The William and Mary Quarterly, 59:1 (2002), p. 47.

${ }^{88}$ On the strategic purpose of the Declaration of Independence, see ibid., pp. 46-50; Mapp, 'The Revolutionary War and Europe's great powers', p. 316.

${ }^{89}$ Bemis, The Diplomacy of the American Revolution, p. 35.

${ }^{90}$ Jonathan R. Dull, A Diplomatic History of the American Revolution (New Haven: Yale University Press, 1985), p. 51.

${ }^{91}$ In Bemis, The Diplomacy of the American Revolution, p. 48.

${ }^{92}$ Jonathan R. Dull, 'Diplomacy of the Revolution, to 1783', in Greene and Pole (eds), A Companion to the American Revolution, p. 354.

${ }^{93}$ Jonathan R. Dull, 'Franklin the diplomat: The French mission', Transactions of the American Philosophical Society, 72:1 (1982), p. 26.

${ }^{94}$ Vergennes, quoted in C. H. Van Tyne, 'Influences which determined the French government to make the treaty with America, 1778', The American Historical Review, 21:3 (1916), p. 533; Edward S. Corwin, French Policy and the American Alliance of 1778 (Hamden, CT: Archon Books, 1916), pp. 122-3.

${ }^{95}$ Dull, 'Franklin the diplomat', p. 29.
} 
them abandon us in despair or in anger, ${ }^{96}$ he used his cunning diplomatic skills to force France's hand. He informed the French foreign minister that a meeting with the British had taken place, which had its intended effect: 'Vergennes reacted with apparent panic, telling his own ambassadors that if France did not reach agreement quickly with America, she would settle with Britain and then the two would attack France. ${ }^{97}$

Whether this was the point that tipped the negotiations in the Americans' favour is difficult to tell. Dull argues that, on the one hand, Vergennes's fears are difficult to take seriously. But he also notes, on the other, that by expressing his fear, he likely helped to convince both the French king and the Spanish that an alliance was necessary. ${ }^{98}$ Nevertheless, what it does demonstrate is the positional power the Americans had acquired in the 1770s. Some of this was not of their own making, as they had little to do with the lack of a rapprochement between France and Britain other than reinforcing the anglophobia already present in French society. ${ }^{99}$ But by binding themselves closer to France, they were in a position from which they could play both against each other, striking the best bargain possible. The end point was a French-American alliance, signed with a treaty of amity and commerce in February 1778. ${ }^{100}$

\section{Angolan War of Independence}

Great power interventions into decolonial struggles during the Cold War are often seen as a by-product of an East-West conflict, during which the two sides carefully managed the global balance of power. The main thrust of the argument for Western intervention into 'Third World' conflicts, for instance, was to contain an expanding Soviet empire whose success would tip the global balance in the Soviets' favour. ${ }^{101}$ It was thus in the American interest to intervene in these conflicts. But, as I argued above, a focus on interests hides the structural constraints and opportunities that allow for these interventions to be successfully conducted. In the following, I will explore this argument further by examining the Angolan War of Independence. ${ }^{102}$ Just as it might have been in the interests for France to intervene in the American Revolutionary War, such interests might be ascribed to both the Soviet Union and the United States in the case of Angola. But just as it might have constrained France had it been allied to Britain, the United States and other Western states were constrained by being closely tied to Portugal. And just as the Americans, due to Britain's splendid isolation, found it significantly easier to mobilise the French, Portugal's integration into the Western alliance meant that there was little hindering Angolans from binding denser ties with the Soviet Union, China, or Cuba.

\section{Angola and the West}

The Portuguese Empire, like many of its European imperial counterparts, held a considerable number of colonies in Africa: Mozambique, Guinea-Bissau, Príncipe, São Tomé, and Angola. Due to the Portuguese effort in the Second World War, its Atlantic presence, and anti-communism, Portugal was well placed within NATO. ${ }^{103}$ In particular, Portugal's possession

\footnotetext{
${ }^{96}$ Arthur Lee's recitation of Franklin, quoted in ibid., p. 29.

${ }^{97}$ Dull, 'Franklin the diplomat', pp. 29-30.

${ }^{98}$ Ibid., p. 30.

${ }^{99}$ Ibid., p. 27.

${ }^{100}$ In Bemis, The Diplomacy of the American Revolution, pp. 62-3.

${ }^{101}$ See also Stephen van Evera, 'Why Europe matters, why the Third World doesn't: American grand strategy after the Cold War', Journal of Strategic Studies, 13:2 (1990), p. 16.

${ }^{102}$ Due to this article's focus on decolonial struggles, I will limit this case study to the war of independence against Portugal, thus excluding external interference in the civil war that followed Angola's independence in 1974.

${ }^{103}$ Glyn Stone, 'Britain and the Angolan revolt of 1961', The Journal of Imperial and Commonwealth History, 27:1 (1999), p. 109.
} 
of the strategically important islands of the Azores made it a strategic partner in the North-Atlantic Alliance. ${ }^{104}$ As such, Portugal's position within the network of Western states hampered Angola's efforts to acquire significant support from the West. Without dense and/or exclusive ties to the West, Angola faced difficulties in mobilising Western states to support its struggle for independence.

Initially, however, it looked as though the United States, in particular, would support Angolans. In the early 1960s, the liberation movement was split into two: the Frente Nacional de Libertação de Angola (FNLA) and the Movimento Popular de Libertação de Angola (MPLA). While the former was both anti-Communist and anti-Western, the latter, led by Angolan Marxists, had closer affinities to the Soviet bloc. ${ }^{105}$ Despite their anti-Western ideological base, however, both movements sought help from the United States. But help from any NATO country would require both significant binding and wedging strategies from the Angolans.

The FNLA leader, Holden Roberto, visited the United States in the late 1950s. ${ }^{106}$ During his visit, Roberto 'gradually developed relationships with liberal members of Congress' and 'had cordial discussions with then-Senator John F. Kennedy'. ${ }^{107}$ Kennedy's inauguration as president less than a month before the outbreak of the war of independence was opportune for the FNLA; not only were ties developed with its leader, Kennedy had also been critical of US support for colonial regimes, in particular of the support offered to the French in Algeria which he had criticised in a Senate speech in 1957. ${ }^{108}$ Kennedy, moreover, was a believer in the Cold War doctrine that these anti-colonial struggles were an opportunity for the Soviets to get a foothold in Africa. ${ }^{109}$ Angolan optimism was not unfounded: Kenney instructed the CIA to send both arms and money to the FNLA. ${ }^{110}$

Encouraged by the FNLA's apparent ability to acquire assistance from the Americans, the Marxist leaders of the MPLA, too, ventured to the United States to form closer ties. Due to its Marxist roots, the MPLA needed to engage in more radical binding strategies than did the FNLA. What proved crucial for the MPLA was the removal of some of the more radical leaders within the movement. ${ }^{111}$ Moreover, the MPLA, in particular, sought to secure American assistance by driving a wedge between the latter and the Portuguese regime. The diplomatic strategy adopted would play on Western economic interests in Angola and 'deepen economic "contradictions" inherent in Lisbon's relations with "imperialist countries in the Western Alliance"'. ${ }^{112}$ If the MPLA leadership could make Western state leaders believe that the way Portugal ruled their African colonies was to the detriment of Western economic interests, and that they would get more economic returns with an independent Angola, they would at least have a clear incentive to break institutional ties with Portugal. Initially, these strategies proved successful: the MPLA was able to convince both the CIA and the State Department that they preferred Western assistance and were not committed to the communist world. ${ }^{113}$

\footnotetext{
${ }^{104}$ George Wright, The Destruction of a Nation: United States' Policy Towards Angola since 1945 (Chicago: Pluto Press, 1997), p. 20.

${ }^{105}$ Odd Arne Westad, The Global Cold War: Third World Interventions and the Making of Our Times (Cambridge: Cambridge University Press, 2005), p. 210.

${ }^{106}$ In fact, in the late 1950s, Holden Roberto was the leader of União das Populaçoes de Angola (UPA), the precursor to FNLA.

${ }^{107}$ Gillian Rosalind Gunn Clissold, 'Coercion versus Co-Optation: Western Relations with the MPLA and FRELIMO from 1956 to 1976' (London School of Economics and Political Science, 2001), p. 29.

${ }^{108}$ Gerald J. Bender, 'American policy toward Angola: A history of linkage', in Gerald J. Bender, James S. Coleman, and Richard L. Sklar (eds), African Crisis Areas and U.S. Foreign Policy (Berkeley and Los Angeles: University of California Press, 1985), p. 111.

${ }^{109}$ Bender, 'American policy toward Angola', p. 111.

${ }^{110}$ Ibid.

${ }^{111}$ As is evident from the 1963 US memorandum quoted in Fernando Andresen Guimarães, The Origins of the Angolan Civil War: Foreign Intervention and Domestic Political Conflict (Basingstoke: MacMillan Press, 2001), p. 68.

${ }^{112}$ Clissold, 'Coercion versus Co-Optation', p. 32.

${ }^{113}$ Inge Tvedten, 'U.S. policy towards Angola since 1975', The Journal of Modern African Studies, 30:1 (1992), p. 33.
} 
Just as the Americans had begun to form denser ties to the French in 1776-7, different factions of the Angolan liberation movements found themselves in close contact with the US, in particular, in the beginning of the 1960s. But whereas the Americans held exclusive ties to the French, Portugal's integration into the Western alliance meant that the Angolans ran the risk of Portuguese interference in their emerging ties to external actors in the West. This, while it was in the interests of the Angolans to build denser ties with the West, such ties cannot be forged at will.

The Portuguese leadership under Salazar adopted, essentially, two different strategies to wedge apart the emerging alliance between Angola and the US: one designed for integrative purposes, the other to fragment the emerging ties between the Angolans and Americans. To respond to the 'economic contradictions' highlighted by the MPLA leadership, Portugal sought to integrate their colonies into a wider web of economic relations. In 1964-5, 'Portuguese investment laws were altered so as to offer broadened guarantees and simplified procedures to foreign capital. ${ }^{114}$ While such an integrative strategy might form closer ties between Portugal and, in particular, the United States, it might also have the opposite effect: the latter might, too, form closer ties with the Angolans through the increased commercial contacts between the two.

The Portuguese had, however, formed a clear fragmenting strategy to ensure that too close bonds between their NATO allies and Angola would not be tied. Portugal was well aware of the strategic importance of the Azores - in Truman's Secretary of State, Dean Acheson's words 'the single most important [base] we have anywhere'115 - and that these islands could be used as a bargaining chip to ensure continuing Western support for the Portuguese case. ${ }^{116}$ In the NATO meetings in the early 1960s, Portugal thus signalled that, in the case of continued support for the Angolans, it might change its attitudes towards the United States and leave NATO. ${ }^{117}$ Kennedy, in response, followed the advice of the State Department, who made it clear that 'any position involving serious risk of the Azores is unacceptable'. ${ }^{118}$

This illustrates the difficulties that colonies face when they form non-exclusive ties to external actors. While one could reasonably claim that the leaders of both MPLA and FNLA formed denser ties with the West, Portugal's position within NATO proved detrimental to Angolan efforts to mobilise support from Western states in the late 1950s and early 1960s. As such, while moving closer to a position of dense and non-exclusive relations to the West, this was not sufficient to mobilise on this side of the iron curtain. Had, counterfactually, Portugal not been a vital NATO member - or were it not in the possession of the Azores - it is conceivable that the leaders of MPLA and FNLA would have achieved significant support from, at least, the Americans. ${ }^{119}$

\section{Angola and the East}

As both types of relations can be defined as exclusive, the relations Angolans developed to the Eastern powers might be equated with the relations the Americans had to France. But whereas the latter operated as a unified peripheral actor, the Angolan War of Independence, as we

\footnotetext{
${ }^{114}$ John Marcum, 'The politics of indifference: Portugal and Africa, a case study in American foreign policy', Issue: A Journal of Opinion, 2:3 (1972), p. 11.

${ }^{115}$ Quoted in Wright, The Destruction of a Nation, p. 41.

${ }^{116}$ On the importance of the Azores for the United States, see Christopher Coker, NATO, The Warsaw Pact and Africa (Hampshire: MacMillan Press, 1985), p. 64; Guimarães, The Origins of the Angolan Civil War, pp. 178-9.

${ }^{117}$ Clissold, 'Coercion versus Co-Optation', pp. 59-60.

${ }^{118}$ Wright, The Destruction of a Nation, p. 45.

${ }^{119}$ While the British, too, did not neglect the institutional ties within NATO in designing its policy towards Portugal, the two states had been allied since the fourteenth century, thus making it more difficult for the Angolans to achieve any significant support from the United Kingdom. See Pedro Aires Oliveira, 'The United Kingdom and the independence of Portuguese Africa (1974-1976): Stakes, perceptions and policy options', Revue Française de Civilisation Britannique, 18:2 (2013).
} 
have seen, was waged by different factions of the population. As such, the different political factions faced different structural constraints in mobilising external actors, also among the Eastern powers. While both the FNLA and MPLA were eager to acquire Western support, the Soviet Union saw, in particular, the FNLA as having developed too 'close ties with American public and semi-official organizations'. ${ }^{120}$ Their leadership was therefore portrayed by Soviet analysts as being a 'puppet of U.S. imperialism'. ${ }^{21}$ This severely hindered the FNLA from acquiring Soviet support.

Other structural constraints made a close union with the Chinese difficult. Initially, China was open to support all political factions of Angola's independence struggle. ${ }^{122}$ But, after the FNLA leadership met China's Foreign Minister Chen Yi in late 1963, a closer relationship did not develop as Chinese personnel was not allowed to enter the Democratic Republic of Congo, the main host state of the FNLA. ${ }^{123}$ While the FNLA still received some military aid from China, no open alliance between the two was ever made. ${ }^{124}$ When a group within the FNLA, in 1964, broke off and formed the União Nacional para a Independência Total de Angola (UNITA), they immediately appealed to China for support, claiming to be following a Maoist doctrine. The Chinese supported UNITA until the early $1970 \mathrm{~s}$, when they began to focus on the MPLA. ${ }^{125}$

The openly Marxist faction, MPLA, was, in contrast, more appealing for the Communist countries. While China, due to the Sino-Soviet split, initially regarded the MPLA as too pro-Soviet, the Soviet Union, and Cuba were all eager to provide assistance. ${ }^{126}$ Both had established contacts with the MPLA leadership during the 1950s. ${ }^{127}$ But, like the FNLA, the MPLA faced impediments due to their ties to the Western states. They therefore needed to demonstrate their allegiance to the Communist states. In 1964, they took an active stance that they would be oriented towards the socialist bloc. As Fernando Andresen Guimarães argues, through this unambiguous position, the MPLA had 'discovered a niche from where it could translate international influence into domestic political advantage and vice versa'. ${ }^{128}$ In 1975, the year of Angola's independence, the Soviets finally made the MPLA a regional ally 'second in importance only to the South African ANC'. ${ }^{129}$

The three main political factions in Angola ended up receiving support for their independence struggles. But it is difficult to conclude that this was simply due to a geopolitical struggle between the two superpowers. After their initial flirtations with the West, it was necessary for both to demonstrate that their allegiances lied with the Communist states. By making their Communist identity more visible, both factions engaged in binding strategies to form closer ties to external actors; the strategy that had failed in mobilising Western states, due to Portugal's position in the Western alliance. In this case, they were by and large successful.

\section{Conclusions}

When the American revolutionaries first approached France for an alliance, and when the different factions in Angola reached out to the Soviet Union and China, all had weak but exclusive ties to the respective external actors. Due to Britain's diplomatic isolation after the Seven Years' War,

\footnotetext{
${ }^{120}$ Jiri Valenta, 'The Soviet-Cuban intervention in Angola, 1975', Studies in Comparative Communism, 11:1 (1978), p. 5.

${ }^{121}$ Harmala Kaur, 'China and the Angolan National Liberation Movement', China Report, 13:4 (1977), p. 26.

${ }^{122}$ Steven F. Jackson, 'China's Third World foreign policy: The case of Angola and Mozambique, 1961-93', The China Quarterly, 142 (1995), p. 394.

${ }^{123}$ Ibid., p. 396.

${ }^{124}$ Kaur, 'China and the Angolan National Liberation Movement', p. 25.

${ }^{125}$ Jackson, 'China's Third World foreign policy', p. 397.

${ }^{126}$ Ibid., p. 396.

${ }^{127}$ Guimarães, The Origins of the Angolan Civil War, p. 264; Valenta, 'The Soviet-Cuban intervention in Angola, 1975'; Edward George, The Cuban Intervention in Angola, 1965-1991 (Abingdon: Frank Cass, 2005), pp. 14-28.

${ }^{128}$ Guimarães, The Origins of the Angolan Civil War, pp. 268-9.

${ }^{129}$ Westad, The Global Cold War, p. 218.
} 
the Americans could approach a host of British enemies for external assistance. And due to Portugal's well-integrated position within the Western alliance, the Angolans could more easily form ties with the East. The binding strategies both used to acquire this assistance increased the density of ties to actors outside their respective imperial structures, and, as such, increased their positional power.

Weak and exclusive and dense and exclusive are only two of four ideal-typical positions a peripheral unit can inhabit, however. Angolans' attempt to form ties with the West illustrates the two others. In particular, it highlights how difficult it is for peripheral units to mobilise external support when the ties forming are non-exclusive. In the American case, we can therefore counterfactually reason what might have happened had the British taken up French efforts to form an alliance in the early 1770s: Britain could, like Portugal did in the Angolan case, wield power to break up any alliance forming.

The American and Angolan cases were utilised to explore the argument that variations in the positional power of peripheries are important in explaining the dynamics that lead to external support. While the empirical focus has been on how great power support were acquired, I have speculated that the framework could also illuminate how the support of 'lesser' powers could play a significant role in waging significant power against the imperial core. The framework could, therefore, serve as a foundation on which future studies of the international networks of contentious colonies are built. Based on the two case studies at hand, however, we can conclude that, while the international system for contentious colonies was less permissive in the nineteenth than in the twentieth century, the illustrative case of the American Revolutionary War demonstrates that the framework can be utilised to explain part of the variation in acquiring external assistance in the nineteenth century. Similarly, although the twentieth century was generally more permissive for great power support, the framework illuminates the difficulties the Angolans faced when trying to mobilise Western states. Together, both cases show that by paying attention to the diplomacy of peripheral actors, we are able to see dynamics that are hidden away in metrocentric studies of imperial relations.

Acknowledgements. I thank the editors and the three anonymous reviewers for their critical engagement and constructive comments. Earlier versions of this article have also benefited greatly from the assistance and insights of Jens Bartelson, Benjamin de Carvalho, Daniel Gustafsson, Martin Hall, Katie Verlin Laatikainen, Joseph MacKay, Håvard R. Markussen, Klas Nilsson, Øyvind Svendsen, and Ted Svensson. I am also grateful for the comments from fellow panelists at several conferences and from the members of the STANCE research group at Lund University.

Sindre Gade Viksand is a PhD Candidate in the Department of Political Science at Lund University. His research focuses on imperialism, internationalism, and the history of international thought.

Cite this article: Viksand, S. G. 2020. Contentious colonies: The positional power of imperial peripheries. Review of International Studies 46, 632-651. https://doi.org/10.1017/S0260210520000170 